\title{
Ethiopia's Developmental Rights to Use Nile River
}

\author{
Mohammed Dilu Hussen \\ College Of Social Science And Humanities, Werabe University, Worabe, Ethiopia
}

\begin{abstract}
This paper reviews the Ethiopia's developmental rights in using Nile River based on principles of international water law related to transboundary water resources management and analyses to what extent these principles are incorporated in recent international conventions and treaties. The study tells that principle of equitable and reasonable utilization, obligation not to cause significant harm, principles of cooperation, information exchange, notification, consultation and peaceful settlement of disputes are widely acknowledged by modern international conventions, agreements and treaties. These principles could facilitate effective transboundary water resources management involving riparian countries of shared watercourses and hence, promote sustainable development around the world.The paper is set out into five sections. The first section begins with a description of Grand Renaissance Dam of Ethiopia and its importance. The second section describes Nile Basin Initiatives (NBI) 1999. The third section deals with International Water law and Qualm Over Nile River. The fourth section of the paper elucidates Theories and doctrines of international water law. The last section discusses the Principles of international water law.Ethiopia has not clung to its natural benefit of being an upstream country. Being a supply of $86 \%$ of the Nile water, it has not claimed absolute territorial sovereignty over the water in its boundaries. Under international water laws Ethiopia would solely be required to notify and share applicable information with downstream nations in order to utilize the river. This is the courtesy that Egypt did not prolong to Ethiopia or the other top riparian states when it used be growing its numerous water infrastructures on the Nile River and diverting the river out of it is herbal course. Ethiopia has no need of harming any one rather than using it is own developmental rights in collaborative and embracing circumstance approach within other riparian nations.
\end{abstract}

DOI: $10.7176 / \mathrm{IAGS} / 89-02$

Publication date: January $31^{\text {st }} 2021$

\section{Introduction}

The Nile River, ((Arabic: Bahr-al-nil or Nahr-Al-Nil) is the longest international river in the world (Swain 2002), with a length of $6,671 \mathrm{~km}$ and a watershed area of about 2850 million square meters.

The Nile River has two main tributaries the Blue Nile (Abay) and White Nile. The White Nile is a modest tributary, contributing only $14 \%$ of the Nile's flow, with water flowing steadily from Lake Victoria and other lakes (Albert, Kiog and Edward) in the central East Africa through Uganda into the Sudd in the Sudan, and then on to Khartoum. The Blue Nile, coming from Ethiopia's highlands (Lake Tana and flows of the eternal snows of the Ruwenzori mountains) is the most important tributary of the Nile River. It is contribution to Nile River is about $86 \%$, which has high seasonal fluctuations due to local climatic conditions in the region. The two tributaries have their confluence in the Sudan at Khartoum; then, further north, the meet another tributary the Atbara River. The Nile River continues to flow into Lake Nasser, which behind the Aswan High Dam in Egypt, and finally into the Mediterranean Sea. Nile River is flow from eleven countries include Tanzania, Burundi, Rwanda, The democratic republic of Congo, Kenya, Uganda, South Sudan, Ethiopia, Sudan and Egypt. 


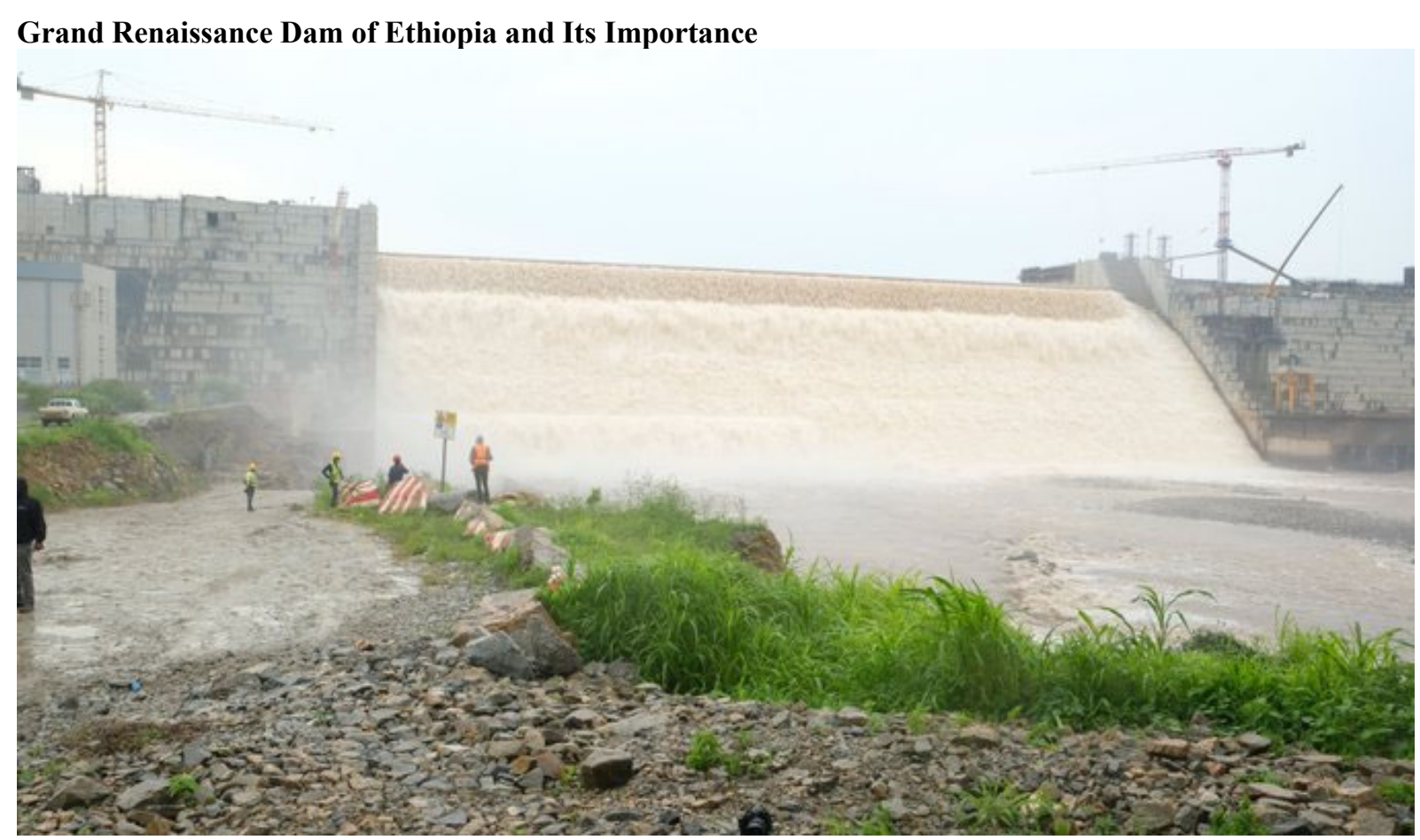

Source: - FBC, 2020

Ethiopia's construction of a dam in the Benishangul Gumuz region on the Blue Nile river near the border with Sudan, known as the Grand Ethiopian Renaissance Dam (GERD) with a reservoir having about 66 BCM capacity, has generated controversy. Ethiopia, Egypt and Sudan have set up an International Panel of Experts to study the impact of GERD. The panel consists of technical representatives of the three countries and independent experts from outside the Nile Basin. There are two dimensions of this project. If the reservoir is too large, it may obstruct flow of water. On the other hand, in some respects the GERD project will benefit Sudan and Egypt. Firstly, it is believed that the construction of this dam will help Sudan trap excessive sedimentation that it encounters and which costs several million dollars to clear. Secondly, the cost of generating power in Ethiopia can be lower than in Sudan and Ethiopia can benefit from power markets in Sudan and perhaps even Egypt. Thirdly, if a coherent water sharing agreement is signed between the three countries, the Dam can help secure a consistent supply of water for agricultural production in the winter months. In order to increase cumulative benefits from the GERD, joint ownership through joint investments can be developed to transform the dam into a joint project by the three states, Ethiopia, Egypt and Sudan ((Tesfa, 2013). The terms of co-ownership may include:

- Construction costs and future maintenance costs of the dam, turbines and the reservoir

- Power trade rates for the investing countries, and the possibility of subsidies for developing industrial clusters

- Future expansion of power exports beyond the three nations to other Nile riparian states, as well as building a potential for power trade to other MENA and African states

- Managing impact of climate change on the dam

- Managing the issue of settlement of communities affected by the project

- Jointly managing the ecological impact of the dam to maximize benefit-sharing from the project as well as to conserve the Nile River for the future. (Tesfa, 2013).

Both Egypt and Ethiopia are heavily relying on Nile's water. Ethiopian population growth rate is equivalent to Egypt establishing on equally compelling need for water for increase food production. Despite the presence of I.LAW no comprehensive deal is signed between these 11 countries on the river Nile basin yet. despite water being a scarce resource. It has been an actor of friction as well as catalyst of peace, as nation are forced to work together desperate but successful example of turning adversaries into improbable partner we've the brilliant example of Indus water treaty and Senegal river treaty. But meanwhile the tension has been continuously scooting in between river Nile sharing countries. The shifting urgency of reaching agreement to reasonably and equitably share benefit on the Nile basin can't be indispensible. The vary process of reaching cooperation would create a stabilizing and more transparent atmosphere in the countries who are staring wile basin. It would widen political, build political stability and spread confidence between states. (ibid) 


\section{NILE BASIN INITIATIVE (NBI) 1999}

A drift for Cooperation the purpose of the Nile treaties mentioned above was to deny the upper riparian's rights to use the waters of the Nile without prior approval of Egypt, rest of the upper riparian states took it as an hegemonic behaviors . "There is understanding in principle that things should modify, yet the nature of change in footing of rights to the water has not been agreed on. Legal principles such as 'just use' and responsibility not to cause harm enunciated in the 1997 Convention on the Non-Navigational Uses of International Watercourses have not been of much help as they place upstream and downstream states in diametrically opposing sides" ( Wolf A.T, 1998).

The need for international agreements over water cannot be challenged because of the accelerative possibility for water-induced conflict owing to scarcity and debasement, which pose a continual threat to domestic, regional and international security. States, armed with autonomous rights to territorial resources, use water to serve political, economic, and social goals. Hydro politics specialists agree that conflict has the hidden potential to emerge when the lower riparian (most vulnerable) nation is militarily stronger than the upper riparian (water-controlling) nation and it feels its interests are jeopardy, as in the case of the Nile River (Gleick P., 2001), the danger of water scarcity and resultant tensions exemplify the relationship between environment and political interests. Alteration in water usage or evolution of water resources poses a gain say to the status quo, which, threatens to alter the quality of life of the nation and restricts policy options. State safety involves the power of states and societies to maintain their free identities, as well as their physical and functional integrity.

Nile Basin Initiative is collaboration among the Nile riparian countries that "seek to develop the River in a combined manner, share significant socioeconomic benefits, and encourage regional peace and security". The NBI begun with a dialogue among the riparian states that resulted in a shared vision objective "to attain socioeconomic development through the equitable utilization of and benefit from the Nile basin water resources", It was formally launched in February 1999, by water ministries of nine countries include Egypt, Sudan, Ethiopia, Uganda, Kenya, Tanzania, Burundi, Rwanda, the Democratic Republic of Congo (DRC), as well as Eritrea as an observer, from its Showtime NBI has been supported by the World bank and by the outside partners. These countries give Mandate to World Bank to support the work of NBI as lead development partner and as a administrator of a multi donor Nile basin trust fund (The Word bank, 2010).

In May 2010, five upstream states signed a "Cooperative framework agreement "to seek more water from river Nile which is heavily criticized by Egypt and Sudan. Ethiopia, Kenya, Uganda, Rwanda and Tanzania were original signatories with Burundi signed it in February 2011. The DRC is also expected to sign, because of its severe drought situation. Representative of the upstream countries said "They were tired of first getting permission from Egypt before using river Nile water for any development project like irrigation" as required by the treaty signed buried the colonial era between Egypt and Britain(Ethiopian led river Nile agreement signed without Egypt and Sudan). The new agreement once effective is specifically design to supersede the Nile basin initiative.

\section{INTERNATIONAL WATERLAW AND QUALM OVER NILE}

The Nile River is presently one of the most disputative Trans boundary water hotspots. As Ethiopia initiated building of the Grand Renaissance Dam (GERD), it compels Egypt and other basin states to re-analyze how the Nile's water is allocated. This situation has the power to result in conflict, but modern international water law can assist these states settle down their differences peacefully. At the Centre of water law are principles regarding the allotment and management of these resources. These principles are planned specifically to boost cooperation, prevent conflict, and provide needed order. The Nile is a historical case study to see how these principles can be applied. The conflict over the Nile's water affected the more developed lower riparian countries Egypt and Sudan against the still developing upper riparian countries including Ethiopia, Uganda, Kenya, Tanzania, Burundi, Rwanda, the Democratic Republic of Congo (DRC), Eritrea, and South Sudan. The lower riparian countries are almost entirely relied on the Nile's water and have historically received a large part of the Nile's flow. Even so, as the upper riparian developing countries they need more water for their drinking water, agricultural irrigation, and hydropower production.

In June 2011, Ethiopia began mount a portion of the Nile as component of its program for the construction of the GERD. Egypt was warned by this move because the GERD is a behemoth size. When complete, it will be the biggest dam in Africa and have a generating capacity of 6,000 megawatts (the equivalent of 6 nuclear power plants). Egypt is afraid that such a dam could reduce the amount of water it receives from the Nile, and because it is a signal that in the future the upper riparian countries will maintain greater power over the Nile.

Neither Egypt nor Ethiopia has gone to war over the Nile's water, but both sides are engaging in statements war. For instance, at a recent forum of Egyptian politicians, it was recommended that the country could undermine dam construction though a conceal military campaign. Ethiopia has long been afraid about such a plot. As late Premier of Ethiopia Meles Zenawi said he was not "upset about that the Egyptians will abruptly invade Ethiopia. Nobody who has tried that has lived to tell the story." Egypt and Sudan rely on archaic treaties. 
Egypt has two principal claims. First, it wants to maintain the outsized quota of water it was allocated by the 1959 Agreement for the Full Usage of Waters. Second, Egypt wants to keep its veto option on upper riparian buildings on river Nile as provided by the 1929 Interchange Notes between Her Majesty's Government in the Great Britain and the Egyptian Government on the Use of Waters for irrigation purpose.

The upstream countries fiercely challenge the legality of these treaties. The 1929 treaty was signed when many of the upper riparian countries were still colonies. Furthermore, these countries were not even parties to the 1959 treaty. Following from the Vienna Convention on the Law of Treaties, the upper riparian countries are likely not bound by these treaties. Against those treaties, the other basin countries have begun ratifying the Cooperative Framework Agreement (CFA). This agreement is the result of the Nile Basin Initiative and is plan for the "mutual benefit and good faith to attain optimal utilization for the development of the Nile's water need .The Cooperative frame work agreement has been signed by Ethiopia, Uganda, Kenya, Burundi, Tanzania and Rwanda and South Sudan. Ethiopia initiates the process of ratification on June 13, 2013. Uganda is expects ratification soon. Egypt has not yet signed this agreement due to his reservations on water quota.18 The CFA has deep originated in international water law and integrates many of its main principles. Water law itself has long promote countries to collaborate over the use of their shared resource. Like much of international law, water law once permit states total sovereignty over activity in their borders. This was reflected in the late nineteenth century Harmon Doctrine. This doctrine stated a state could tap natural resources within its borders without interference. This antiquity has been rejected by most states.

A starting point for the development of water law's collaborative framework was the 1911 Madrid Declaration, which stated that countries sharing a water resource are "in a position of permanent physical dependence on each other." Today, international laws incorporate norms for sharing a water resource and how it must be allocated and used. There are 2 major principles of recent water law that are relevant to the Nile River. The first principle is that the equitable use doctrine, that outlines the quantum what quantity water every state ought to be allowed to require from the shared resource. This was declared within the 1966 Helsinki Rules on the Uses of the Waters of International Rivers that describes the principle as entitling every state "within its territory, to a reasonable and equitable share in the beneficial uses of the waters of an international drainage basin." Later international conventions and declarations have endorsed this principle. This philosophy anticipates that a watercourse might not contain enough water for all states, however that a balance is found wherever the requirements of all states is addressed. The CFA endorses the equitable use doctrine. The second doctrine is basin wide management. As described by the first U.N Secretary General, Dag Hammarskjöld all states which share the resource should be jointly included in the management of the river. This was reiterated by the law Association that represented the geographic region as "an integrated whole" and discouraged "piecemeal" development. A common means that this common management is applied is the' the creation of a joint establishment. The CFA provides for the creation of the Nile River Basin Commission (NRBC) to handle the requirements of basin states. It is clear that the 1929 and 1959 treaties seemingly don't bind the upper riparian states, and these countries are not mirroring contemporary law. In distinction, the CFA does represent trendy water law, although it's not nevertheless gone into force. However, the principles made public higher than do indicate some solutions to this conflict. First, Egypt's arrange to management brim over half the Nile's water violates the just use principle. This is clearly way more than its share, although it clearly includes a claim to a sizeable quantity. For its half Ethiopia cannot claim a lot of the water or its use than it's entitled to. This may be specific relevant within the issue of hydropower production, and it may well be needed to produce a number of this electricity to other basin states Second, Ethiopia's unilateral construction of the GERD while not the opposite Nile River Basin states' approval violates the thought of basin wide management. The same might be same for Egypt's commit to maintain the establishment water allocations. Although the NRBC has not nevertheless been created, there are unit still organizations like the Nile River Basin Initiate that area unit supposed to facilitate such management. Egypt must absolutely interact with the NBI and sign the CFA. Ethiopia must secure the agreement and cooperation of its co-riparian states 19 The River defies tries to seek out a straightforward answer. The watercourse doesn't have enough water for would like the requirements the wants of all basin states nevertheless all countries need water to continue economic development. The construction of the Grand Ethiopian Renaissance Dam is among the primary unilateral developments which will considerably impact the Nile's water, however it's hardly the last. The risks for conflict are high, however international water law's principles of equitable use and basin wide management offer steering for Abyssinia and Egypt as they conceive to share this common heritage of mankind.

\section{Theories and doctrines of international water law}

The theoretical foundation of the principles of international water law related to trans-boundary water resources management evolves from different theories and doctrines. This section summarizes three major ones:

1. Theory of absolute territorial sovereignty

2. Theory of absolute territorial integrity 
3. Theory of limited territorial sovereignty.

1. Theory of absolute territorial sovereignty

Every nation can utilize the waters of an international river flowing on its territory, as it likes, regardless of the consequences in other countries and without the duty to consult (Correia and Silva, 1999). According to this theory, the upstream states would be free to divert all the water from a shared watercourse without considering the need for downstream states (McCaffrey, 1996, p.549).

This theory also known as the "Harmon Doctrine", after the US Attorney General, Mr. Judson Harmon, who declared the absolute right of the USA to divert the Rio-Grande in 1895 . He commented, "The fact that the Rio Grande lacks sufficient water to permit its use by the inhabitants of both countries does not entitle Mexico to impose restrictions on the USA which would hamper the development of the latter's territory or deprive its inhabitants of an advantage with which nature had endowed it and which is situated entirely within its territory. To admit such a principle would be completely contrary to the principle that USA exercises full sovereignty over its national territory" (Birnie and Boyle, 2002, p.332).

However, most modern experts dismiss this doctrine. Even the USA promptly retreated from the Harmon doctrine in treaties with Mexico (1906 Convention between the USA and Mexico concerning the equitable distribution of the waters of the Rio Grande for irrigation purposes) and Canada (1909 Treaty between the UK and the USA concerning boundary waters and questions arising along the boundary between Canada and the USA) that are consistent with the theory of limited territorial sovereignty which is discussed below. This theory has a little support in state practice and does not represent international law (Birnie and Boyle, 2002, p.301; Salman and Uprety, 2002, p.12).

\section{Theory of absolute territorial integrity}

This theory is based on the assertion that the lower riparian of an international river has the right to a full flow of water of natural quality and interference with the natural flow by the upstream state require the consent of the downstream riparian. Therefore, the lower riparian has the right to claim the continued and uninterrupted flow of water from the territory of the upper riparian, 'no matter what the priority' (Barandat and Kaplan, 1998; Schroeder-Wildberg, 2002). Often downstream states support this theory as it guarantees them the use of an international river in an unaltered condition. Like the Harmon doctrine, this theory has limited support in state practice, jurisprudence or the writings of commentators (Birnie and Boyle, 2002, p.302).

\section{Theory of limited territorial sovereignty}

This theory is based on the assertion that every state is free to use shared rivers flowing on its territory as long as such utilization does not prejudice the rights and interests of the co-riparian. In this case, sovereignty over shared water is relative and qualified. The co-riparian's have reciprocal rights and duties in the utilization of the waters of their international watercourse and each is entitled to an equitable share of its benefits. This theory is also known as theory of sovereign equality and territorial integrity. The advantage of this theory is that it simultaneously recognizes the rights of both upstream and downstream countries as its guarantees the right of reasonable use by the upstream country in the framework of equitable use by all interested parties. Principles of equitable and reasonable utilization and obligation not to cause significant harm are the part of the theory of limited territorial sovereignty (Schroeder-Wildberg, 2002, p.14). Only this theory has gained wide acceptance and formed the basis of modern international water law (Salman, 2007a, p.628).

\section{Principles of international water law}

Article 38 (1) of the 1946 Statute of the International Court of Justice (ICJ) is generally recognized as a statement of the sources of international law. Article 38 (1.a) requires the court to apply international conventions, whether general or particular, expressly recognized by the contesting states. Article 38 (1.b) requires the court to apply international customs as evidence of general practice accepted as law. Article 38 (1.c) requires the court to apply the general principles of law recognized by civilized nations. This section summarizes some important customary and general principles of international law applicable to trans-boundary water resources management that are accepted globally and incorporated in modern international conventions, agreements and treaties.

\section{Principle of equitable and reasonable utilization}

This use-oriented principle is a sub-set of the theory of limited territorial sovereignty. It entitles each basin state to a reasonable and equitable share of water resources for the beneficial uses within its own territory (Article IV of the Helsinki Rules 1966 and Article 5 of the UN Watercourses Convention, 1997). Equitable and reasonable utilization rests on a foundation of shared sovereignty, equality of rights and it does not necessarily mean equal share of waters. In determining equitable and reasonable share relevant factors, such as the geography of the basin, hydrology of the basin, population dependent on the waters, economic and social needs, existing utilization of waters, potential needs in future, climatic and ecological factors to a natural character and availability of other resources should be taken into account (Article V of the Helsinki Rules, Article 6 of the UN Watercourses Convention and Article 13 of the Berlin Rules). It entails a balance 
of interests that accommodates the needs and uses of each riparian state. This principle has substantial support in state practice, judicial decisions and international codifications (Birnie and Boyle, 2002, p.302). The ICJ's 1997 decision concerning the Gabcikovo-Naymaros Project endorsed the theory of equitable and reasonable utilization that was incorporated in Article 5 of the UN Watercourses Convention. This principle is incorporated in 1966 Helsinki Rules (Articles IV, V, VII, X, XXIX [4]), 1997 UN Watercourses Convention (Articles 5, 6, 7, 15, 16, 17, 19), 1995 SADC protocol on shared watercourse systems (Article 2), 2002 Sava River Basin Agreement (Articles 7-9), 1996 Mahakali River Treaty (Articles 3, 7, 8, 9), 1995 Mekong Agreement (Articles 4-6, 26), 2004 Berlin Rules (Articles 10.1, 12, 13, 14, 16) and 1992 UNECE Water Convention (Article 2.2c).

\section{Obligation not to cause significant harm}

This principle is also a part of the theory of limited territorial sovereignty (Eckstein, 2002, p.82). According to this principle, no state in an international drainage basin are allowed to use the watercourses in their territory in a way that would cause significant harm to other basin states or to their environment, including harm to human health or safety, to the use of the waters for beneficial purposes or to the living organisms of the watercourse systems. This principle is widely recognized by international water and environmental law (Khalid, 2004, p.11). However, question remains on the definition or extent of the word 'significant' and how to define 'harm' as a 'significant harm'. This principle is incorporated in most modern international water conventions, treaties and agreements. It is now considered as part of the customary international law (Eckstein, 2002, pp.82-83). This principle is incorporated in 1966 Helsinki Rules (Articles V, X, XI, XXIX [2]), 1997 UN Watercourses Convention (Articles 7, 10, 12, 15, 16, 17, 19, 20, 21.2, 22, 26.2, 27, 28.1, 28.3), 1995 SADC protocol on shared watercourse systems (Article 2), 2002 Sava River Basin Agreement (Articles 2, 9), 1996 Mahakali River Treaty (Articles 7, 8, 9), 1995 Mekong Agreement (Articles 3, 7, 8), 2004 Berlin Rules (Articles 8, 10.2, 16) and 1992 UNECE Water Convention (Articles 2.1, 2.3, 2.4, 3). This principle is also acknowledged by modern international environmental conventions and declarations, e.g. 1972 Stockholm Declaration of the UN Conference on Human Environment (Principles 21, 22), 1992 Rio Declaration on Environment and Development (Principles 2, 4, 13, 24) and 1992 Convention on Biological Diversity (Article 3).

\section{Principles of notification, consultation and negotiation}

Every riparian state in an international watercourse is entitled to prior notice, consultation and negotiation in cases where the proposed use by another riparian of a share watercourse may cause serious harm to its rights or interest. These principles are generally accepted by international conventions, agreements and treaties. However, naturally, most upstream countries often oppose this principle. It is interesting to note that during the negotiation process of the 1997 UN Watercourses Convention, these principles, which are included in Articles 11 to 18, were opposed by only three upstream riparian countries: Ethiopia (Nile basin), Rwanda (Nile basin) and Turkey (Tigris-Euphrates basin) (Birnie and Boyle, 2002, p.319).

Article 3 of the International Law Association's (ILA) Complementary rules applicable to international resources (adopted at the 62nd conference held at Seoul in 1986) states that"when a basin State proposes to undertake, or to permit the undertaking of, a project that may substantially affect the interests of any cobasin State, it shall give such State or States notice of the project. The notice shall include information, data and specifications adequate for assessment of the effects of the project" (Manner and Metsälampi, 1988).

These principles are incorporated in most modern international water conventions, treaties and agreements, e.g. 1966 Helsinki Rules (XXIX [2], XXIX [3], XXIX [4], XXX, XXXI), 1997 UN Watercourses Convention (Articles 3.5, 6.2, 11-19, 24.1, 26.2, 28, 30), 1960 Indus Waters Treaty (Articles VII [2], VIII), 1995 SADC protocol on shared watercourse systems (Articles 2.9, 2.10), 2002 Sava River Basin Agreement (Parts Three and Four, Article 22), 1996 Mahakali River Treaty (Articles 6, 9), 1995 Mekong Agreement (Articles 5, 10, 11, 24), 2004 Berlin Rules (Chapter XI, Articles 57, 58, 59, 60) and 1992 UNECE Water Convention (Article 10). These principles are also acknowledged by modern international environmental conventions and declarations, e.g. 1992 Rio Declaration on Environment and Development (Principles 18, 19) and 1992 Convention on Biological Diversity (Article 27.1).

Principles of cooperation and information exchange It is a responsibility for each riparian state of an international watercourse to cooperate and exchange data and information regarding the state of the watercourse as well as present and future planned uses along the watercourse (Birnie and Boyle, 2002, p.322). These principles are recommended by 1966 Helsinki Rules (Articles XXIX, XXXI) while Articles 8 and 9 of the 1997 UN Watercourses Convention makes these an obligation. These principles are incorporated in most modern international water conventions, treaties and agreements, e.g. 1966 Helsinki Rules (Articles XXIX [1], XXIX [2], XXXI), 1997 UN Watercourses Convention (Articles 5.2, 8, 9, 11, 12, 24.1, 25.1, 27, 28.3, 30), 1960 Indus Waters Treaty (Articles VI-VIII), 1995 SADC protocol on shared watercourse systems (Articles 2-5), 2002 Sava River Basin Agreement (Articles 3-4, 14-21), 1996 Mahakali River Treaty (Articles 6, 9, 10), 1995 Mekong Agreement (Preamble, Articles 1, 2, 6, 9, 11, 15, 18, 
24, 30), 2004 Berlin Rules (Chapter XI, Articles 10, 11, 56, 64) and 1992 UNECE Water Convention (Articles 6, 9, 11, 12, 13, 15, 16). These principles are also acknowledged by modern international environmental conventions and declarations, e.g. 1972 Stockholm Declaration of the UN Conference on Human Environment (Principles 13, 22, 24), 1992 Rio Declaration on Environment and Development (Principles 7, 9, 12, 13, 17, 27), 1992 Convention on Biological Diversity (Articles 5, 17).

\section{Peaceful settlement of disputes}

This principle advocates that all states in an international watercourse should seek a settlement of the disputes by peaceful means, in case states concerned cannot reach agreement by negotiation. Most modern international water conventions, treaties and agreements incorporated this principle, e.g. 1966 Helsinki Rules (Articles XXVI-XXXVII), 1997 UN Watercourses Convention (Article 33), 1960 Indus Waters Treaty (Article IX, Annexure F, G), 1995 SADC protocol on shared watercourse systems (Article 7), 2002 Sava River Basin Agreement (Articles 1, 22-24, Annex II), 1996 Mahakali River Treaty (Articles 9, 11), 1995 Mekong Agreement (Articles 18.C, 24.F, 34, 35), 2004 Berlin Rules (Articles 72-73) and 1992 UNECE Water Convention (Article 22, Annex IV). This principle is also acknowledged by modern international environmental conventions and declarations, e.g. 1992 Rio Declaration on Environment and Development (Principle 26) and 1992 Convention on Biological Diversity (Article 27, Annex II).

\section{Analysis of the international water law}

The process of evolution and codification of international water law related to navigational purposes commenced with the adoption of the Act of the Congress of Vienna in 1815 (Salman and Uprety, 2002, p.8). From a global point of view, the 1868 Mannheim Convention on navigation on the Rhine among Belgium, France, Germany and The Netherlands is one of the major multilateral treaties related to water (Hughes, 1992, p.84). This convention adopted the recommendations of the 1815 Congress of Vienna and 1831 Convention of Mainz. The key principles of this convention were the obligation of the member states to maintain the Rhine river waterway and ensuring freedom of navigation along the Rhine (CCNR, 2007). The Convention and Statute on the Régime of Navigable Waterways of International Concern, widely known as Barcelona Convention, was adopted at Barcelona on 20th April 1921. These early conventions, however, dealt with navigational uses of trans-boundary watercourses. Subsequent rapid industrialization and increased demands for water resources propelled innovation in the law that is applicable to the nonnavigational water uses, such as flood control, hydropower development, water quality management and water allocation (Biswas, 1999, p.437). As a consequence, non-navigational rules have become eminent in subsequent state practice and water conventions. For a detail analysis of the evolution of international water law, see Salman and Uprety (2002, pp.8-31). This section scrutinizes the Helsinki Rules (1966), UN Watercourses Convention (1997) and Berlin Rules (2004) in order to find out to what extent principles related to trans-boundary water resources are incorporated in modern international conventions.

The Helsinki rules on the uses of the waters of international rivers (1966)

The ILA adopted the Helsinki Rules on the Uses of the Waters of International Rivers at the 52nd conference, held at Helsinki in August 1966. This document is widely known as the Helsinki Rules and, over the years, it has become widely acknowledged as bases for negotiation among riparian states over shared waters (Birnie and Boyle, 2002; Eckstein, 2002). 1966 Helsinki Rules are predominantly relevant for non-navigational uses of trans boundary waters, even though Articles XII-XX also address the navigational uses.

Article II defines 'international drainage basin' as a geographical area extending over two or more states determined by the watershed limits of the system of waters, including surface and underground waters, flowing into a common terminus.

Article IV ascertains the principle of equitable and reasonable utilization of the water resources of the international drainage basin by stating, "Each basin State is entitled, within its territory, to a reasonable and equitable share in the beneficial uses of the waters of an international drainage basin". Articles V, VII, X, XXIX (4) also recommend this principle.

Article $\mathrm{V}$ defines the relevant factors that should be considered in determining the reasonable and equitable share of water resources in an international drainage basin. These factors include but are not limited to (Article V, paragraph II):

- The geography of the basin, including the extent of the drainage area in the territory of each basin state.

- The hydrology of the basin, including the contribution of water by each basin state.

- The climate affecting the basin.

- The past utilization of the waters of the basin, including in particular existing utilization.

- The economic and social needs of each basin state.

- The population dependent on the waters of the basin in each basin state. 
- The comparative costs of alternative means of satisfying the economic and social needs of each basin state.

- The availability of other resources.

- The avoidance of unnecessary waste in the utilization of waters of the basin.

- The practicability of compensation to one or more of the co-basin states as a means of adjusting conflicts among uses.

- The degree to which the needs of a basin state may be satisfied, without causing substantial injury to a co-basin state.

The inclusion of the term 'without causing substantial injury' in Article V (II) demonstrates the adoption of the principle 'not to cause significant harm'. Articles X, XI, XXIX (2) also endorse this principle. Articles IX-XI provides provisions for controlling pollution of an international drainage basin on the basis of the principle of equitable utilization. It is interesting to note that the paragraph 1(a) of the Article X uses the principle of 'not to cause significant harm' in controlling pollution. It mentions,

1. "Consistent with the principle of equitable utilization of the waters of an international drainage basin, a State must prevent any new form of water pollution or any increase in the degree of existing water pollution in an international drainage basin which would cause substantial injury in the territory of a co-basin State".

Article XI binds the responsible state to cease wrongful conduct and compensate the injured co-basin state for the injury, in case of the violation of the rule stated in paragraph 1(a) of Article X. Thus, any kind of human conduct that causes water pollution falls in the boundary of the 'not to cause significant harm' principle. However, controversy remains, as the term 'substantial injury' is not clearly defined. In addition, 'injury' does not always necessarily equate with 'harm' and 'substantial' does not always equate with 'significant'.

Articles XXVI-XXXVII of the Helsinki Rules deal with the procedures for the prevention and settlement of the disputes. The key objective is to prevent or settle the disputes by peaceful means (Article XXVII). Paragraph 1 of the Article XXIX recommends each basin state to furnish relevant available information to the other basin states concerning the waters of a drainage basin within its territory. Paragraph 2 of Article XXIX asserts that: "A State, regardless of its location in a drainage basin, should in particular furnish to any other basin State, the interests of which may be substantially affected, notice of any proposed construction or installation which would alter the regime of the basin in a way \} and the notice should include such essential facts as will permit the recipient to make an assessment of the probable effect of the proposed alteration". Articles XXX and XXXI recommend to settle the disputes by negotiation and by forming a joint agency to formulate plans and recommendations for the most efficient use of the waters of an international drainage basin. Article XXXII recommends states to request mediation of a third party, of an international organization or of a qualified person, if necessary.

Articles XXXIII- XXXVII deal with the guidelines for disputes settlement and arbitration mechanisms, in case the states concerned have not been able to resolve their disputes through negotiation or have been unable to agree on the measures described in Articles XXXI and XXXII. This reveals that the 1966 Helsinki Rules endorse the principles of cooperation, information sharing, consultation, notification, negotiation and peaceful settlement of disputes. The Helsinki Rules were later supplemented by the ILA's subsequent resolutions, e.g. the 1982 Montreal Rules on Pollution and the 1986 Seoul Complementary Rules. Recently, the Helsinki Rules and subsequent resolutions have been revised by the ILA's 2004 Berlin Rules. While the Helsinki Rules are relatively important in the development of international water law, it is worth mentioning that they were drafted by the ILA, a professional organization, and hold no official status internationally (Biswas, 1999, p.438). The work of ILA has always been regarded as inspirational and not as hard and fast rules for state conduct (Eckstein, 2002). But although they are unofficial we should accord them great value because subsequent modern bilateral and regional treaties have tended to adopt the guidelines provided by the Helsinki Rules. Over the years, these guidelines have played a significant role in the development and codification of international water law (Eckstein, 2002). Nevertheless, despite their soundness and applicability, the Helsinki Rules and their supplementary declarations have enjoyed a little recognition as official codification of international water law. To overcome this indefiniteness, in 1970, the UN General Assembly commissioned the International Law Commission (ILC) to draft a set of articles to govern non-navigational uses of transboundary waters. Operating under the UN, the work of ILC is highly regarded as an official codification of international water law. After 21 years of extensive work, in 1991, the ILC prepared the draft text of the UN Watercourses Convention (Biswas, 1999, p.438). 4.2 UN convention on non-navigational uses of international watercourses (1997) after considerable discussion during 1991-1997 on the ILC's draft, on 21st May 1997, the UN General Assembly adopted the Convention on NonNavigational Uses of International Watercourses, widely known as the UN Watercourses Convention. This Convention codified the principles of sharing international watercourses building on the 1966 Helsinki Rules (UNDP, 2006, p.218). Upon the request by Turkey, the General Assembly of the United Nations called for a vote on the resolution 51/229 adopting the UN Watercourses Convention. Out of 133 nations, 103 nations votes in favor (including Bangladesh, Finland, Jordan, Syria, USA, Mexico Slovakia and Nepal), 27 nations abstained 
(including Egypt, Ethiopia, India, Israel, Rwanda and France) and three nations votes against the Water Convention (Burundi, China and Turkey) (IWLP, 2008). According to Article 36(1) of the Convention 35 instruments of ratification, approval, acceptance or accession are necessary to bring the Convention into force. The Convention was open for signature from 21 May 1997 until 20 May 2000 (Article 34). States or regional economic integration organizations, however, may continue to ratify, accept, approve or accede to the Convention indefinitely (Article 36). As of 9 January 2008, only 16 countries ratified or consented to be bound (acceptance, approval or accession) by the UN Watercourses Convention (cf. Table 1). For an in depth analysis of the reasons for the reluctance of states to become parties to Convention, see Salman (2007b).

Even though this Convention is not in force yet, it contains the general customary principles of international water law that have been developed by the work of international judicial bodies and scholars of relevant field (Khalid, 2004). The following section briefly analyses the scopes of the relevant articles of the UN Watercourses Convention in relation to the principles of the international water law. According to the Article 1(1), the scope of the Convention applies to non-navigational uses of international watercourses and their waters. The navigational uses are out of the scope of the Convention except insofar non-navigational uses affect navigation or are affected by navigation (Article 1, paragraph 2). Article 2 of the convention defines 'international watercourse' as a system of surface waters and ground waters constituting by virtue of their physical relationship a unitary whole and normally flowing into a common terminus, parts of which are situated in different states. Article 5 adopts the theory of equitable and reasonable utilization: "Watercourse States shall in their respective territories utilize an international watercourse in an equitable and reasonable manner. In particular, an international watercourse shall be used and developed by watercourse States with a view to attaining optimal and sustainable utilization thereof and benefits therefrom, taking into account the interests of the watercourse States concerned, consistent with adequate protection of the watercourse". Article 5(2) requires watercourse states to participate and cooperate in the use, development and protection of the watercourse in an equitable and reasonable manner. Article 6(1) mention that all relevant factors and circumstances should be taken into account in determining equitable and reasonable utilization. These factors include:

- Geographic, hydrographic, hydrological, climatic, ecological and other factors of a natural character.

- Social and economic needs of the watercourse states concerned.

- Population dependent on the watercourse in each watercourse state.

- Effects of the use or uses of the watercourses in one watercourse state on other watercourse states.

- Existing and potential uses of the watercourse.

- Conservation, protection, development and economy of use of the water resources of the watercourse and the costs of measures taken to that effect.

- The availability of alternatives, of comparable value, to a particular planned or existing use. In the application of Articles 5 and 6(1), Article 6(2) requires states to enter into consultations in a spirit of cooperation. However, Biswas (1999, p.439) notes that none of these factors mentioned in Article 6(1) can be defined precisely as they are broad and general. Accordingly, these can be defined and quantified in a variety of different ways. Preamble and Article 24(2) highlight the need to manage international watercourse by promoting the rational and optimal utilization, protection and control of the watercourse. Article 7 of the convention approves the principle of the obligation not to cause significant harm in its paragraph 1: "Watercourse States shall, in utilizing an international watercourse in their territories, take all appropriate measures to prevent the causing of significant harm to other watercourse States". Article 7(2) obliges all states to comply the provisions of Articles 5 and 6 to eliminate or mitigate significant harm on another watercourse state. Article 10 states that any conflict among uses of an international watercourse shall be resolved with reference to Articles 5-7. Articles 12, 15, 16, 17 and 19 forbid implementation of any planned measures on an international watercourse that are inconsistent with the provisions of Articles 5 and 7. Article 27 calls for taking appropriate measures to prevent or mitigate conditions that may be harmful to other watercourse states, whether resulting from natural causes or human conduct, such as flood, siltation, erosion, water-borne disease and drought. In the Working Group of the UN Watercourses Convention, Bangladesh voted in favour for of the Articles 5-7 whereas India abstained (Schroeder-Wildberg, 2002, p.33). The principles of cooperation and information exchange are endorsed by the UN Watercourses Convention. Article 8(1) advocates the general obligation to cooperate for the optimal utilisation and adequate protection of the international watercourses. Article 8(2) encourages the riparian countries to establish joint mechanisms or commissions to facilitate cooperation. Article 9 obliges the watercourse states to exchange the data and information on the state of the watercourse particularly that of a hydrological, meteorological and ecological nature and related to the water quality as well as related forecasts. Article 24(1) endorses the idea of joint management mechanism of the international watercourse. Article 25(1) stipulates, "Watercourse States shall cooperate, where appropriate, to respond to needs or opportunities for regulation of the flow of the waters of an international watercourse". Part III of the UN Watercourses 
Convention (Article 11-19), Articles 24(1), 26(2), 27, 28 and 30 incorporate the principles of cooperation, information exchange, notification, consultation and negotiation. Articles 11-19 describe the detailed procedures for the information exchange, notifications, consultations and negotiations on any planned measure in an international watercourse. Article 11 stresses: "Watercourse States shall exchange information and consult each other and, if necessary, negotiate on the possible effects of planned measures on the condition of an international watercourse". Article 12 makes notification of the planned measure in an international watercourse obligatory and states, "Before a watercourse State implements or permits the implementation of planned measures which may have a significant adverse effect upon other watercourse States, it shall provide those States with timely notification thereof. Such notification shall be accompanied by available technical data and information, including the results of any environmental impact assessment, in order to enable the notified States to evaluate the possible effects of the planned measures". Article 24(1) stipulates, "Watercourse States shall, at the request of any of them, enter into consultations concerning the management of an international watercourse, which may include the establishment of a joint management mechanism". Article 26(2) requires states to enter into consultation in case any installations, facilities and other works related to an international watercourse causes or poses to cause significant adverse effects to watercourse states. In case of emergency situation that causes, or poses a threat of causing, serious harm to watercourse states, Article 28(2) requires all watercourse states to notify other states by the most expeditious means. Paragraphs 3 and 4 of the Article 28 call for cooperation among all potentially affected states to prevent mitigate and eliminate harmful effects of the emergency situations and to develop contingency plan for responding to emergencies. In the absence of direct contacts among the watercourse states, Article 30 recommends cooperation, data and information sharing, notification, consultations and negotiations through any indirect procedure accepted by the states concerned. Thus, these articles endorse the principles of cooperation, information exchange, consultation, notification and negotiation. Articles 20-22 attribute the protection and preservation of watercourse ecosystems on the basis of the doctrine not to cause significant harm. Article 21 necessitates the preservation and protection of the watercourse ecosystems. Paragraph 2 of the Article 21 entails watercourse states to individually and/or jointly prevent, reduce and control the pollution of the international watercourse that may cause significant harm to other watercourse states, or to their environment, including harm to human health, to the use of any beneficial uses of the waters or to the living resources of the watercourse. Article 22 recommends all states to prevent the introduction of alien or new species that may cause significant harm to ecosystem and other watercourse states. Thus, Articles 21 and 22 widen the scope of the 'not to cause significant harm' principle that is adopted in Article 7(1) of the Convention, to preserve watercourse ecosystems as well as human health. It also recommends watercourse states to take steps to harmonize their policies for preserving watercourse ecosystems. Article 33 of the Convention provides detailed provisions for settlement of disputes. Article 33(1) states that in the absence of agreement, all states shall settle the disputes by peaceful means in accordance with the provisions of Article 33. China and India both objected this article pointing to the compulsory provisions regarding the disputes settlement. India asserted that "[a]ny procedures for peaceful settlement of disputes should leave the procedure to the parties" (Eckstein, 2002, p.84). Although the Convention is not in force yet, the principles adopted by the Convention have become norms of international legal practice and contribute towards progressive development and codification of international water law (cf. Birnie and Boyle, 2002; Eckstein, 2002, p.89; Salman and Uprety, 2002; Giordano and Wolf, 2003, p.167). Even prior to its adoption, the ILC's draft articles has significantly influenced number of international agreements and regional treaties, such as 1992 UNECE Convention on the Protection and Use of Transboundary Watercourses and International Lakes, the 1995 SADC Protocol on Shared Watercourse Systems (revised in 2000), the 1995 Mekong river basin agreement (Eckstein, 2002). The ICJ has also referred this Convention in the 1997 Gabcikovo-Nagymaros case which is described in subsection 4.3.

\section{Gabcikovo-nagymaros case}

ICJ's decision of 25th September 1997 on the case, concerning the GabcikovoNagymaros project (ICJ, 1997) is a good example of the international applicability of the doctrine of equitable utilisation and obligation not to cause significant harm. This case shows that an international watercourse is constrained in part by the limits of equitable use, in part by evolving environmental obligations and in part by considerations of sustainable development (Birnie and Boyle, 2002, p.316). The ICJ was presented with a controversy between Hungary and Czechoslovakia over a 1977 bilateral treaty on the Danube river regulating the development of a series of installations for improving the hydro-power generation, the environment and navigation, flood and ice control on the Danube River. The main feature of the 1977 Hungary-Czechoslovakia treaty was the development of 
hydroelectric power and navigation, with projects to be carried out in each country at its own expense. The dispute arose when Hungary unilaterally suspended the work (13th May 1989) on its portion causing Czechoslovakia (now Slovakia) in turn to unilaterally implement 'Variant C', one of the Czech/Slovak alternatives for developing the relevant section of the Danube. Variant $\mathrm{C}$ created a major decrease in the flow of Danube River downstream in Hungary (paragraph 65 of ICJ, 1997). Both countries had undergone dramatic political changes. Hungary determined that the project was environmentally unsound and attempted to unilaterally terminate the 1977 Treaty. On the other hand, Czechoslovakia/Slovakia argued that the project was environmentally sound, and that if any environmental issues arose, they could be adequately addressed within the 1977 treaty. The ICJ deliberated the case for four years, and decided in 1997 that both Hungary and Czechoslovakia/Slovakia had committed internationally wrongful acts and both parties are under an obligation to pay compensation (paragraph 152). The ICJ required that the settlement of accounts for the construction of the works must be resolved in accordance with the 1977 Treaty and related instruments (paragraph 154). The ICJ decided the case on general international treaty law, but referred to Article 5 (paragraph 2) of the UN Watercourses Convention that focuses equitable and reasonable utilization of water resources in paragraph 147. The decision reads, "Re-establishment of the joint régime will also reflect in an optimal way the concept of common utilization of shared water resources for the achievement of the several objectives mentioned in the Treaty, in concordance with Article 5, paragraph 2, of the Convention on the Law of the Non-Navigational Uses of International Watercourses". The court concluded that by implementing Variant C, Czechoslovakia/Slovakia violated the basic right of Hungary to the equitable and reasonable share of the Danube river water (Stec and Eckstein, 1997, p.45). ICJ decision held that (paragraph 85): "Czechoslovakia, by unilaterally assuming control of a shared resource, and thereby depriving Hungary of its right to an equitable and reasonable share of the natural resources of the Danube - with the continuing effects of the diversion of these waters on the ecology of the riparian area of the Szigetköz - failed to respect the proportionality which is required by international law". The ICJ also decided (paragraph 152): "Hungary is entitled to compensation for the damage sustained as a result of the diversion of the Danube, since Czechoslovakia, by putting into operation Variant $\mathrm{C}$, and Slovakia, in maintaining it in service, deprived Hungary of its rightful part in the shared water resources, and exploited those resources essentially for their own benefit." The ICJ endorsed the theory of equitable and reasonable utilization that is incorporated in Article 5 of the 1997 UN Watercourses Convention. This is evidence that 1997 UN Watercourses Convention is strengthening the modern development of international law and legal practices, despite its status is not being in force (cf. Stec and Eckstein, 1997, p.45; Eckstein, 2002; Khalid, 2004).

\section{The Berlin rules on water resources (2004)}

On 21 August 2004, the Berlin Rules on water resources were approved in ILA's 71st conference held in Berlin. Unlike the Helsinki Rules and UN Watercourses Convention, the Berlin Rules include not only the development of important bodies of international environmental law, but also international human rights law and the humanitarian rights law relating to the war and armed conflict (Salman, 2007a, p.635). Chapter II (Articles 4-9) addresses the principles of international law governing the management of all waters. Articles 5 and 6 recognize the need for conjunctive and integrated management of water resources. Article 5 recommends states to manage surface waters, groundwater and other sources of water conjunctively. Article 6 recommends states to integrate appropriately the management of waters with the management of other resources. Article 8 requires states to take all appropriate measures to prevent or minimize environmental harm. Chapter III (Articles 10-16) deals with internationally shared waters. Article 10 ascertains that basin states have the right to participate in the management of waters of international drainage basin in an equitable reasonable and sustainable manner. Article 12 mentions: "Basin States shall in their respective territories manage the waters of an international drainage basin in an equitable manner having due regard for the obligation not to cause significant harm to other basin States" (p.7). Salman (2007a, p.636) observe that the Helsinki Rules and UN Watercourses Convention emphasize the right of each basin state to reasonable and equitable share. On the other hand, Berlin Rules obliges each basin state in international drainage basin to manage water in equitable and reasonable manner. Article 13(2) provides the list the relevant factors that should be considered in determining the equitable and reasonable use referred in Article 12. In addition to the factors listed in Article 6(1) of the UN Watercourses Convention, Berlin Rules include two new factors to be considered, i.e. the sustainability of proposed or existing uses and the minimization of environmental harm. Article 14 (1) explicitly mentions that in determining equitable and reasonable use, allocation of waters to satisfy vital human needs should receive the first preference over the other uses of water. Article 16 requires states to refrain from and prevent acts within their territory that causes significant harm to another basin state. Article 11 requires basin states to cooperate in good faith for in the management of waters of an international drainage basin. Chapter XI deals with international cooperation and administration. Article 56 requires basin states to exchange relevant and available information on the quantity and quality of waters. Article 64 recommends basin states to establish basin wide commission or joint agency to ensure the equitable and sustainable use of waters and the prevention of harm. Articles 57, 58, 59 and 60 
acknowledge that each basin state is entitled to receive prior notice, consultation and negotiation in cases where the proposed programme, plan, project or activity may cause significant effect to its rights or interest. Chapter XIV (Articles 72-73) provides detail provisions for the peaceful settlement of international water disputes as well as guidelines for arbitration and litigation. It should be noted that although the ILA is influential, their proposals, these rules have no force unless: 1 the UN adopts them in a convention of some sort 2 the IJC uses the rules in a ruling 3 a transboundary water sharing agreement is adopted them somewhere in the world.

The current electricity access in Ethiopia is $27 \%$, which is very low compared to international standards; it can increase up to $75 \%$ by 2040 using the renewable energy potential of the country. The present study observed that out of the various renewable energy sources, geothermal and solar are less utilized (around $0.2 \%$ ), which could be the key source for rural electrification. In the off gird area, diesel generators are used for electricity access, which can be replaced by solar or wind sources. However, energy production using renewable energy sources is increasing day by day in Ethiopia.

More than $99 \%$ of the Egyptian has access to electricity; while number of customers reached $29.7 \%$ million FY 2012/2013.

\section{Conclusion}

As Ethiopia is the major source of Nile River. It is known that $86 \%$ of the Nile waters and sediment reaching Egypt originate from Ethiopia's highlands. Despite such potential, the majority of Ethiopians has no access to electricity supply or experiences energy insecurity. The primary objective of GERD project is to generate an electric power to cover the basic power supply demand in Ethiopia as well as in East Africa Region.

Due to this Ethiopia has natural and legal right to use its fair share of the Nile River. Egypt has been denying the equal rights to utilize Nile River among the riparian states. Ethiopia has the sovereign right to use its river waters equitably and reasonably and consistent with international law.

Egypt mainly mentions involving their rights to the water pertains to the 1959 bilateral "agreement" signed between Egypt and Sudan allocating the whole goes with the flow of the Nile River exclusively between them. This agreement gives Egypt the lion's share of the Nile River water, 55.5 BCM of the Nile waters ought of 84 $\mathrm{BCM}$ of the Nile waters, denying the upper stream countries even a drop, such as Ethiopia which contributes $86 \%$ of the Nile waters.

There is a longstanding principle of international water law that states fair \& equitable use of trans boundary waters. But there is nothing real looking equitable about the 1959 agreement. No one denied Egypt's right and fair share to the Nile waters, sincerely now not Ethiopia. The emphasis should however be on the phrases "fair share' which can solely come out of a reasonable and equitable utilization which is inclusive of all the eleven riparian states and not an exclusive bilateral colonial treaty between the two downstream states.

Ethiopia has not clung to its natural benefit of being an upstream country. Being a supply of $86 \%$ of the Nile water, it has not claimed absolute territorial sovereignty over the water in its boundaries. Under international water laws Ethiopia would solely be required to notify and share applicable information with downstream nations in order to utilize the river. This is the courtesy that Egypt did not prolong to Ethiopia or the other top riparian states when it used be growing its numerous water infrastructures on the Nile River and diverting the river out of it is herbal course. Ethiopia has no need of harming any one rather than using it is own developmental rights in collaborative and embracing circumstance approach within other riparian nations.

Ethiopia as the member of international community believe in the principle of equitable and reasonable utilization, obligation not to cause significant harm, principles of cooperation, information exchange, notification, consultation and peaceful settlement of disputes that widely acknowledged by modern international water conventions, agreements and treaties. These principles form the basis of the 1966 Helsinki Rules on the Uses of the Waters of International Rivers, 1997 UN Convention on Non-Navigational Uses of International Watercourses and 2004 Berlin Rules on Water Resources. These internationally accepted principles could serve as the guiding principles and provide a framework for further dialogue among the riparian states of shared watercourses for creating effective transboundary water resources management and hence, promoting sustainable development.

\section{References}

Barandat, J. and Kaplan, A. (1998) 'International water law: regulations for cooperation and the discussion of the international water convention', in W. Scheumann and M. Schiffler (Eds), Water in the Middle East: Potential for Conflicts and Prospects for Cooperation. Berlin: Springer, pp.11-30.

Birnie, P. and Boyle, A. (2002) International Law and the Environment. New York, NY: Oxford University Press.

Biswas, A.K. (1999) 'Management of international rivers: opportunities and constraints', Water Resources Development, Vol. 15, pp.429-441.

Correia, F.N. and Silva, J.E. (1999) 'International framework for the management of transboundary water 
resources', Water International, Vol. 24, pp.86-94.

Ethiopian led river Nile agreement signed without Egypt and Sudan, (Accessed on 03:15 pm 29 August 2018).

Gleick P., 'Question of Equity at the Heart of Water conflict management,' Water and Conflict prevention (The Second World Water Forum, The Hague. 17-22 March 2001).

Hughes, D. (1992) Environmental Law (2nd ed.). London, UK: Butterworths.

http://opiniojuris.org/2013/07/16/emerging-voices-international-water-law-preventing-conflict-on-the-nile/ (Accessed on 02:40 pm 1 September 2018) 19 Ibid p,3 (Accessed on 02:40 pm 1 September 2018)

Khalid, A.R.M. (2004) 'The Interlinking of rivers project in India and international water law: an overview', Chinese Journal of International Law, Vol. 3, pp.553-570.

International Court of Justice (ICJ) (1997) Case Concerning the Gabcikovo-Nagymaros Project (Hungary v. Slovakia), General List No. 92, 25 September 1997.

Manner, E.H. and Metsälampi, V-M. (1988) The Work of the International Law Association on the Law of International Water Resources. Finland: Finnish Branch of International Law Association.

McCaffrey, S.C. (1996) 'The harmon doctrine one hundred years later: buried, not praised', Natural Resources Journal, Vol. 36, pp.549-590.

Salman, M.A.S. (2007a) 'The helsinki rules, the UN watercourses convention and the berlin rules: perspectives on international water law', Water Resources Development, Vol. 23, pp.625-640.

Salman, M.A.S. (2007b) 'The united nations watercourses conventions 10 years later: why has its entry into force proven difficult?', Water International, Vol. 32, pp.1-15.

Salman, M.A.S. and Uprety, K. (2002) Conflict and Cooperation on South Asia's International Rivers: A Legal Perspective. Washington, DC: The World Bank.

Schroeder-Wildberg, E. (2002) The 1997 International Watercourses Convention - Background and Negotiations. Germany: Technical University of Berlin.

Stec, S. and Eckstein, G.E. (1997) 'Of solemn oaths and obligations: the environmental impact of the ICJ's decision in the case concerning the gabciko-nagymaros project', Yearbook of International Environmental Law, Vol. 8, pp.41-50.

Tesfa. Benefit of Grand Renaissance Dam Project (GERDP) for Sudan and Egypt. EIPSA Communicating Article, Energy, Water, Environment \& Economic 2013;1(1): 1-12.

UNCED (United Nations Conference on Environment and Development) (1992) Agenda 21.

UNESCO and Green Cross International (2003) From Potential Conflict to Cooperation Potential: Water for Peace. Japan: UNESCO and Green Cross International.

United Nations Development Programme (UNDP) (2006) Human Development Report 2006. New York, NY: UNDP. United Nations Environment Programme (UNEP) (2002) Atlas of International Freshwater Agreements. Kenya: UNEP.

WSSD (2002). Report of the World Summit on Sustainable Development, A/Conf. 199/20. Wolf A.T., 'Conflict and Cooperation along International Waterways' Water Policy, Volume 1 \# 2, 1998, 251.

The Word bank 2010,pgs 90-95"Sustaining water for all in a changing climate: World bank group implementations progress report. 